\section{Vietnam in space}

\section{Queue-jumping}

The recent 8-day sojourn of Vietnamese cosmonaut Pham Tuam aboard the Salyut-6 space station marked a significant change in the Comecon Interkosmos joint space programme. For the first time the non-Soviet participant came from a developing and non-aligned country - a point which both the Soviet and Vietnamese press agencies stressed at the expense of comment on the scientific content.

Phan Tuam's flight, moreover, meant a change in the projected running order of participation, which, most Baikonur watchers had accepted, was related to the size of the contribution the various countries had made to the earlier unmanned stage of the Interkosmos programme (the Interkosmos satellites and Vertikal high-altitude probes). In effect, this meant that the European nations of the bloc would go first, with Cuba and Mongolia bringing up the rear. Vietnam, which joined Comecon in summer 1978, long after all the other members had their cosmonaut candidates installed at the Gagarin space centre, seemed destined for the final place in the programme.

However, with four countries still to go (Romania, and the three non-European members), Vietnam was unexpectedly advanced three places. Both TASS and VNA stressed unequivocally that that there were political implications in this move. Whatever the reason for the changed schedule, however, the interesting question remains: what, precisely could Vietnam contribute to the space programme?

It would be incorrect to suggest that the developing members of Comecon - Cuba, Mongolia and Vietnam - have nothing to offer the Interkosmos programme, or at the most can offer only sites for tracking stations. As early as 1978, the Polish cosmonaut Miroslaw Hermaszewski said that Cuba and Mongolia were working on their experimental programmes for when their turns came. (At that time, Vietnam had still not joined the Interkosmos programme.) Pham Tuam's programme, as reported to date, corresponds remarkably well with those of the other non-Soviet cosmonauts.

First, and inevitably, came the medical programme, the testing of cardiovascular and lung functions under zero gravity. Then, equally routine, experiments on semiconductor crystal growth - in this case, gallium phosphide and a triple bismuth-antimony-tellurium compound. These experiments use a Soviet furnace aboard Salyut-6, but the test capsules come from the non-Soviet participant, which also provides a suitable symbolic name for the project - Morava for Czechoslovakia, Berolina for East Germany and so on. This time, it was Halong, after a gulf in Vietnam.
Not surprisingly, the regular photographic and visual observations carried out from Salyut were given a Vietnamese slant. Silting up of the river mouths, and the effect this has on fish feeding habits, observations of tidal flooding and erosion, and hydrological surveys of the Mekong and Red River Basins were especially stressed. And, most Vietnamese of all, Pham Tuam had taken along samples of azola water ferns, fast-growing, nitrogenrich plants which are traditionally used as fertilizers for the growing rice crop, and which could prove useful aboard future permanent space stations.

Comecon doctrine concerning its third world projects (including its own three "developing"' members) firmly eschew the concept of "aid". All such undertakings are termed "cooperation", projects, although recent bilateral scientifictechnological cooperation deals signed between Vietnam and, for example, Czechoslovakia and East Germany consist largely of the European partner providing experts and know-how, and Vietnam reciprocating with raw materials. Nevertheless, no attempt has been made, as far as Interkosmos is concerned, to present the joint Soviet-Vietnamese flight as a partnership of technological equals. While by no means a passenger, Pham Tuam characterized his role rather as a harbinger of things to come. "It is a new demon-

\section{Shuttle for orbit}

The US National Aeronautics and Space Administration has screwed up its courage and settled on a launching date for the first orbiting version of the space shuttle - March 1981. The decision was taken at the end of last month and in the face of the setback a few days earlier when a fire damaged a shuttle engine during a test firing in Mississippi.

The decision follows a week-long review of the recent ups and downs of the development of the shuttle, and has apparently been taken in the belief that only a tight schedule will sufficiently concentrate the minds of those involved in putting the first shuttle (called Columbia) into an Earth orbit.

The timetable now agreed would move Columbia from the building it now occupies at Cape Canaveral to the shed in which it will be mated with the solid fuel boosters on 23 November. Thereafter it will be mounted on its launch pad and the main engines of the shuttle will be fired for a period of 20 seconds some time in February. Thereafter, there will be five weeks to the final launch date.

Although anxiety persists about the tiles intended to provide thermal shielding for the shuttle, it has apparently been decided not to encumber the first flight with the "tile repair kit" intended to enable the crew of the shuttle craft to replace damaged tiles in flight. stration of the effective cooperation within the socialist community", he said before embarking, which "will also demonstrate the abilities of the Vietnamese people".

Vera Rich

\section{Airport noise \\ London's out}

The Noise Advisory Council (NAC) has provided some timely ammunition for the opponents of the plan to build the third London Airport at Stansted in Essex. Last week, hard on the heels of the formal application for permission to develop the airport by the British Airport Authority, the council announced that the Stansted site will be marginally more of a noise nuisance than the other five sites on the airport authority's short-list.

The application for development permission has gone to the Essex County Council. There will be a public inquiry on the proposals, probably early next year. That will be the second occasion on which the people of Stansted have been divided into hawks and doves.

Choosing a site for London's third airport has already taken 27 years. The chief problem has been that cost-benefit analyses yield equivocal results even when they themselves, like the Roskill Commission of 1968-70, cost more than $£ 2$ million. Uncertainty about the growth of demand for air travel has also taken the steam out of what seemed to be an urgent problem ten years ago.

According to NAC, Maplin, situated on the north of the Thames estuary, would disturb nearby residents least but would require the removal of a Ministry of Defence establishment - which might create environmental problems of its own - and the building of new road and rail links into London. It would also disrupt local bird life. Stansted, an inland site north of London, would be the cheapest site to develop - it already has a small airport, which could be extended, and good links with London, but it is situated near several small towns. The NAC report estimates that 17,000 people would find aircraft noise a nuisance if a two-runway airport were built.

Estimates of annoyance caused by aircraft noise are themselves equivocal. The Noise Advisory Council quotes values of the Noise-Number Index, calculated in such a way as to correlate with surveys of the extent to which people are annoyed by aircraft movements. One difficulty in using this index as a basis for assessing the impact of new airports is that the calibration has been based on surveys at established airports, such as Heathrow, where residents have to some degree become accustomed to aircraft noise after long exposure. Further difficulties stem from uncertainty about flight paths, the noisiness of future aircraft and the future volume of air traffic.

The NAC report says that the noise dis- 
advantage of Stansted over the other sites, excluding Maplin, is only marginal. But it recommends that if Stansted is chosen, local residents should be compensated either in the form of noise insulation or by grants to enable them to move house. It further adds that Stansted could be justified on environmental grounds only if it reduced the total environmental impact of London's airports, especially Heathrow, where about one and a half million people live within the contour of noise annoyance. Hitherto, the case for a third airport has been to absorb increases in demand for air travel rather than to take pressure off existing airports.

The airports authority's proposal for Stansted is for a one-runway airport capable of handling 15 million passengers a year - considerably smaller than a previous proposal thrown out in 1965-66 to build an airport for 100 million passengers a year. One of the additional attractions of the Stansted site is that the existing airport could be enlarged gradually to meet changes in demand.

Judy Redfearn

\section{Polish water \\ Much and little}

Last month's floods, which produced emergency conditions in 22 out of the 49 provinces of Poland and caused a massive loss of crops, especially hay, potatoes and sugar beet, have focused attention once again on the paradox of Poland's water supply. Ranking only twenty-second in Europe in per capita water index $\left(1,700 \mathrm{~m}^{3}\right.$ a year compared with the European average of $4,800 \mathrm{~m}^{3}$ a year), Poland is nevertheless subject to periodic inundations after which the water runs off uselessly into the Baltic. At best, Poland can store only 5 per cent of the water it receives from natural precipitation and incoming rivers. (Bulgaria, Czechoslovakia and the Soviet Union, by contrast, store 12-15 per cent.) Along Poland's largest river, the Vistula, there is no storage capacity whatsoever.

To remedy this, the Central Committee of the Polish United Workers' Party adopted on 16 June 1978 a resolution calling for a multi-disciplinary development and management programme for the Vistula. "Program-Wisla", as it is called, got off the ground very rapidly, at least on the theoretical and planning side. Polish geographers, hydrographers, economists, agriculturalists and ecologists produced imaginative plans which include hydroelectric stations, irrigation works, the improvement of navigation channels, the construction of retaining walls and some 34 or 35 dams along the navigable course of the river between Oswiecim (Auschwitz) and Gdansk. The whole scheme, which is intended to raise Poland's water storage capacity to 20 per cent, as well as benefiting agriculture, industry and the human environment, is scheduled for completion by the end of the century.

So vast an enterprise, say the planners, is nevertheless beyond the capacity of Poland alone, and there will be major scope for international cooperation. But before the Vistula is confined by the engineers into what will be, in effect, a series of basins, the water must be of acceptable purity, since once the natural scour is eliminated, the ecologists agree that the river would not regenerate itself. The Vistula (like Poland's other major river, the Odra) has no water of class I or II purity anywhere in its course, while one-third of its total length is polluted beyond the limit of toleration. Purification and regeneration of the river is the first priority of Program-Wisla.

The problem, however, is far from simple. The headwaters of the Vistula are subject to natural "pollution" by mineral salts leached out of the soil of Silesia. The river flows through the Silesian industrial belt and the Cracow-Nowa Huta conurbation, with its vast steel mills, and past the open-cast sulphur mines at Tarnobrzeg. It picks up its largest tributary, the Bug, already heavily polluted by the Soviet pulp and paper industry, passes through Warsaw, whose sewerage arrangements are, to say the least, antiquated, through Plock with its mushrooming petrochemical plant and finally arrives in the Bay of Gdansk where pollution is so heavy that water-sports are prohibited.

There are nevertheless some bright spots in this picture. The Tarnobrzeg mines, in particular, are managed on strict ecological principles, with recultivation of the land section by section as soon as the sulphur is stripped. Water control there, say the mine engineers, has to prevent seepage from the river to the mine rather than the reverse. The Bug, the one part of the Vistula basin not entirely under Polish control, has just been made the subject of a special PolishSoviet cooperation agreement. And week after week, the Polish media stress the emphasis being given to anti-pollution measures, effluent treatment and the introduction of closed cycle technology under the aegis of Program-Wisla.

Such technology or the exchange of know-how could well be a fruitful field for international cooperation, both within and outside the Comecon bloc. But Polish experts have hitherto been cool at the prospect of Western cooperation, feeling that their prospective partners have been more interested in selling existing standard equipment than providing know-how specifically tailored to Polish circumstances. Since the Polish economy suffers from a chronic lack of hard currency, this is a major problem. The latest negotiations, between Poland and the United Kingdom, seem to be taking a different and - from the Polish point of view - a more promising course. It is understood that before any concrete proposals are put forward from the British side, a small investigative team will visit Poland in the autumn to make an on-the-spot assessment.

Vera Rich

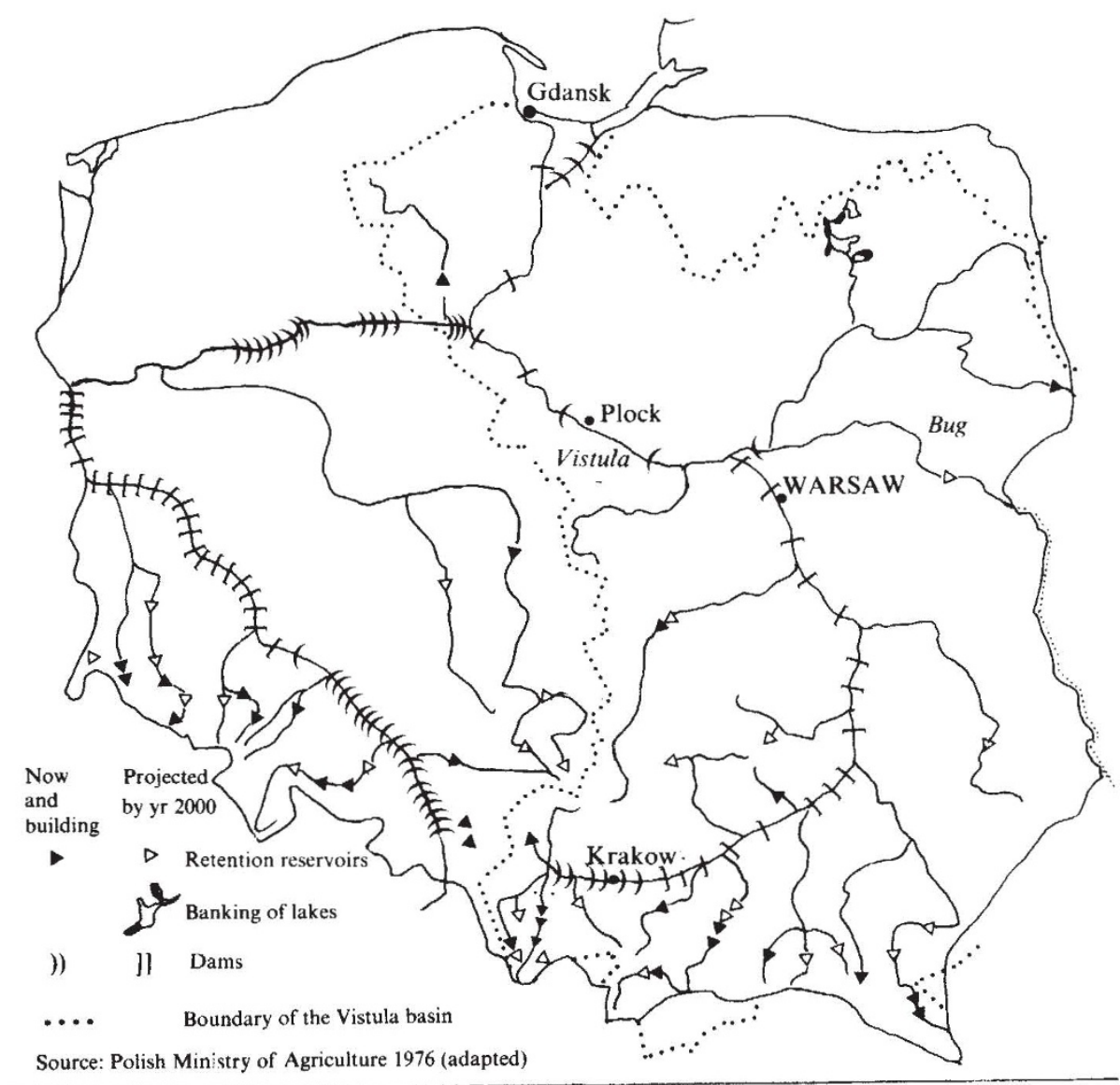

